\section{William Warner Moss, Jr.}

William Warner Moss, Jr., John Marshall Professor of Government and Citizenship, Emeritus, died on March 6, 1993, aged 91. He received his A.B. degree from the University of Richmond and his M.A. and Ph.D. degrees from Columbia University. After serving as assistant professor at New York University from 1928 to 1937 , he came to the College of William and Mary to be chairman of the government department. He retained that position until 1966 , with a brief interval in Washington during World War II when he served with the Office of Price Administration and the Office of Strategic Services. From 1966 until his retirement in 1972 he served as director of the Marshall-Wythe Institute for Research in the Social Sciences at William and Mary.

Warner came to William and Mary with the characteristically New Deal belief that public service is a noble and worthwhile enterprise. He also believed that Virginia and the College could provide a model of service for the nation, as it had once before. He wrote:

Nowhere in America was there ever such a dedication to public service as in the agrarian squirarchy of Virginia. In no commonwealth has the tradition of public service been so continuously recognized as in Virginia. For one hundred years William and Mary helped establish that tradition.

He believed that the early strength of the College lay in its close relationship with the political life of the Virginia colony, but its future lay in the national arena, "as a seminary for statesmen." In 1941 he wrote of his new department:

The Department of Government could not dedicate itself to a greater service to the Nation and the Commonwealth than by training in citizenship and public service the students who come within the range of its influence.

From the beginning, Warner Moss believed that William and Mary should be a national institution. He recruited for his department in the very best universities, and those who joined him were educated by teachers who were leading the emerging disci- pline of political science. He himself was trained in political psychology, which he applied to the study of political parties, and his pioneering work on Irish parties is still treated with great respect. He was firmly wedded to the ideal of a liberal education. He believed, for example, that political science has roots in all the fields of study related to manlanguages, philosophy, science, literature, and the arts. "Those who study men's laws," he wrote, "cannot ignore men's songs." He also believed that lines are drawn too sharply within the social sciences, and in his own training he sought to bridge them.

Warner Moss also brought very practical experience to his academic work, and he expected his colleagues to be active in public affairs. He himself worked in political campaigns in New York, and very soon after his arrival at the College, in 1939, he served as a member of the Committee on Personnel Administration of the Virginia Legislative Council, one of many such experiences.

Warner Moss was a founding father of the modern William and Mary. He encouraged the College to realize its promise as an institution of the first rank. He was instrumental, for example, in having the College recruit nationally for its highest positions, and he always encouraged it to break away from narrow parochialism. He was not always popular with the Board of Visitors, or in Richmond, but he was right, and in the year of his retirement it was fitting that he should have been awarded the College's highest award for service, the Thomas Jefferson Award.

Warner Moss was an exceptional man. He was a liberal who came home to an illiberal state at an illiberal time. But he worked for better days, which came. He was a man of unfailing courtesy, who treated his colleagues with respect and delighted in their success. He was a fine teacher of many generations of students.

Alan J. Ward College of William and Mary

\section{Barbara Ann Salert}

Barbara Salert, associate professor of political science at Washington University in St. Louis, died on March 9 following a long illness, four days before her 45th birthday.

Barbara did her graduate work and taught at Indiana University before joining the department of political science at Washington University in 1975. Her scholarship was mainly in two fields, comparative politics and formal theory and methodology, with most of her published work focusing on political violence and revolution. In addition to writing a number of articles in these areas, her book, Revolutions and Revolutionaries: Four Theories, was published in 1976, and in 1980 she co-authored, with John Sprague, a monograph on The Dynamics of Riots (ICPSR Methodology Series). At the time of her death she and Victor Le Vine were completing a study of the effects of control measures on the incidence of exported terrorism; it will be published early next year. She was a member of the Executive Council of the Midwest Political Science Association from 1972 to 1982 , and served on the editorial boards of The American Political Science Review and The American Journal of Political Science.

Barbara cared deeply for her students and gave a great deal of her time and herself to their nurture and intellectual growth. She served them and the department as graduate student advisor, and though virtually house-bound during the last two years of her life, was never too busy to see or talk to a student, to read or critique students' or colleagues' writings, or to find ways of helping the several graduate students working or writing dissertations under her direction. She also served the department in a number of key assignments, and while she was still able to do so, contributed greatly to the university as a member of several important committees.

To her colleagues and many friends, Barbara was a source of inspiration and strength; she listened, she counseled, she argued, and she shared her remarkable intellect, her insight, her sardonic wit, and above all her warmth as a fine and sensitive human being. 